\title{
AGROSAINSTEK
}

Jurnal Ilmu dan Teknologi Pertanian

Website jurnal : http://journal.ubb.ac.id/index.php/agrosainstek

Artikel Penelitian

\section{Uji Analisis Tingkat Kematangan dan Metode Perendaman terhadap Aspek Fisik dan Kimia Lada Putih (Muntok White Pepper)}

\section{Analysis of Mature and Physiological Aspects of Soaking Method Physical and Chemical White Pepper (Muntok White Pepper)}

\author{
Riwan Kusmiadi ${ }^{*}$, Sitti Nurul Aini', Nurkholis ${ }^{1}$ \\ 1Jurusan Agroteknologi, Fakultas Pertanian, Perikanan, dan Biologi, Universitas Bangka Belitung. Jl. Raya \\ Balunijuk, Bangka 33215
}

Diterima : 13 Mei 2016/Disetujui : 10 Januari 2017

\begin{abstract}
One of the problem an industrial pepper in Indonesia is the lower quality of production by the farmers. To overcome these problem we must have to do research to get a good technique in pepper procesing and the good quality of pepper in accordance Indonesian National Standard. This research using by a factorial randomized block design with three replications of two treatment factors. The first factor is physiologic mature (M) and the second factor is soaking method $(P)$. The research phase includes the preparation of tools and materials. Soaking pepper, cleaning the skin and stems, drying and analysis of pepper quality test. Changes observed in this research is the content of water, the level of colored pepper, and the levels of mold contamination. The result of this research shown the mature phisiologically signifcant effect on the levels of pepper blackish in color and content of seeds lightly. Pepper levels blackish color shown on the higest passing phase that is optimum ripe $0.12 \%$ and the lower passing phase optimum ripe is $0.01 \%$. The higest levels of seed lightly on shown at the mature phase towards optimum ripe $1.66 \%$ and the lower it show through the mature phase that is $0.71 \%$. White pepper research results both in treatment and in the treatment of physiologically mature immersion method meet the Indonesian National Standard.
\end{abstract}

Key Words : White Pepper (Muntok White Pepper), Quality, Mature, Submersion

ABSTRAK

Salah satu masalah perindustrian lada di Indonesia adalah rendahnya kualitas yang diproduksi oleh petani. Untuk mengatasi masalah ini perlu dilakukan penelitian untuk mendapatkan teknik yang baik dalam memproses lada dan menghasilkan kualitas lada sesuai Standar Nasional Indonesia. Penelitian ini menggunakan rancangan acak faktorial dengan tiga kali ulangan. Faktor pertama adalah matang fisiologis (M) dan faktor kedua adalah metode perendaman (P). Tahap penelitian meliputi persiapan alat dan bahan, Perendaman lada, membersihkan kulit dan batang, pengeringan dan analisis uji mutu lada. Peubaha yang diamati dalam penelitian ini adalah kadar air, kadar warna lada, dan tingkat kontaminasi jamur. Hasil penelitian ini menunjukkan efek matang fisiologis memberikan pengaruh yang nyata pada kadar lada kehitam-hitaman dan biji enteng. Kadar lada kehitam-hitaman menunjukan tertinggi pada fase lewat matang optimum $0,12 \%$ dan terendah saat menjelang matang optimum $0,01 \%$. Kadar biji enteng menunjukan tertinggi pada saat menjelang matang optimum $1,66 \%$ dan terendah pada saat lewat matang optimum $0.79 \%$. Hasil penelitian lada putih baik dalam perlakuan metode perendaman dan perlakuan matang fisiologis untuk memenuhi Standar Nasional Indonesia.

Kata kunci: White Pepper (Muntok White Pepper), Kualitas, Kematangan, Perendaman 


\section{Pendahuluan}

Lada (Piper nigrum L.) merupakan salah satu produk tertua dan terpenting dari produk rempahrempah yang diperdagangkan di dunia. Indonesia merupakan negara produsen lada terbesar ketiga di dunia di bawah Vietnam dan India. Salah satu daerah penghasil lada di Indonesia adalah Provinsi Kepulauan Bangka Belitung yang terkenal dengan penghasil lada putih (Muntok White Pepper). Menurut Badan Pusat Statistik Kepulauan Bangka Belitung (2015), produksi lada putih di Bangka Belitung sekitar 33.828 ton pada tahun 2014.

Pengolahan lada putih ditingkat petani khususnya di Bangka Belitung masih dilakukan secara tradisional, umumnya belum memperhatikan efisiensi pengolahan, segi kebersihan dan konsistensi mutu. Pengolahan lada secara tradisional relatif memiliki banyak kelemahan, baik dari segi efisiensi waktu, jumlah tenaga kerja maupun kualitas lada putih yang dihasilkan. Menurut Usmiati dan Nurdjanah (2006) pada Periode 2000-2004 volume dan kontribusi ekspor lada Indonesia terhadap pasar dunia cenderung mengalami penurunan dengan laju berturut-turut $9,2 \%$ dan 15,5\%. Terlepas dari fluktuasi produksi lada Indonesia, penyebab utama menurunnya ekspor lada Indonesia yaitu bervariasinya mutu lada yang dihasilkan, meningkatnya standar mutu yang dikehendaki negara-negara konsumen lada. Dilihat dari sisi pendapatan petani, belum optimalnya efisiensi pengolahan dan rendahnya mutu yang dihasilkan menyebabkan kehilangan nilai tambah yang seharusnya diperoleh petani.

Faktor yang perlu diperhatikan dalam menghasilkan mutu lada putih yang baik sesuai dengan SNI diantaranya adalah penanganan panen dan pascapanen lada. Penanganan panen yang dimaksud adalah harus diketahuinya umur panen buah lada yang tepat serta ukuran matang fisiologis buah lada karena setiap umur panen buah lada dan matang fisiologis yang berbeda memiliki tingkat kematangan dan kandungan kimia yang berbeda pula. Menurut Pruthi (1992) dalam Jumiaty dan Ferry (2011) yang menyebabkan perbedaan kandungan kimia pada buah lada adalah karena terjadinya perubahan beberapa senyawa kimia yang terjadi selama proses menjelang matang penuh, terutama dengan meningkatnya kandungan pati, serat dan piperin. Hasil penelitian yang dilakukan Risfaheri (2012) menunjukan bahwa komposisi kadar minyak atsiri

*Korespondensi Penulis.

E-mail: kusmiadi@gmail.com (R. Kusmiadi) dan piperin menunjukkan peningkatan sampai menjelang matang penuh dan setelah itu menurun selama periode pemasakan buah. Pemanenan untuk lada putih hanya buah lada yang telah matang dapat dipanen, dengan satu atau dua buah biji lada yang telah berubah warna menjadi kuning sampai kemerahan dapat dipetik. Buah harus dipetik secara selektif, dan panen harus dilakukan sesering mungkin selama musim panen. Seringnya dilakukan pemetikan selama musim panen, dapat diharapkan buah lada yang di petik menjadi seragam. Bila pemetikan lada hanya dilakukan satu atau dua kali selama musim panen, kemungkinan buah yang tidak matang akan ikut terbawa (Direktorat Pascapanen dan Pembinaan Usaha 2012). Setelah mengetahui umur panen dan matang fisiologis lada putih yang baik selanjutnya adalah memperhatikan penanganan pascapanen lada.

Faktor penanganan pascapanen yang dimaksud adalah memperhatikan metode perendaman buah lada. Saat ini banyak petani lada yang kurang memperhatihan metode perendaman yang baik. Menurut Putro (2001) dalam Usmiati dan Nurdjannah (2006) masalah utama yang sering dikeluhkan oleh importir rempah Eropa terhadap produk lada Indonesia yaitu tingginya kadar kotoran dan kontaminasi mikroorganisme. Hasil analisis produk lada putih petani Indonesia umumnya mengandung kadar lada hitam 3-13\%, sedangkan syarat mutu IPC 1-2\%. Menurut Direktorat Pascapanen dan Pembinaan Usaha (2012) perendaman dapat dilakukan dalam karung atau keranjang, dalam air yang mengalir atau kolam perendaman dan harus terendam sepenuhnya. Jika perendaman dilakukan dalam air yang tidak mengalir, harus dilakukan penggantian air paling tidak dua hari sekali dan Perendaman dalam air yang mengalir harus dipastikan bahwa tidak ada aktivitas sehari-hari yang dilakukan dibagian hulunya.

Usmiati dan Nurdjannah (2006) melaporkan lama waktu perendaman sampai dengan 12 hari dengan melakukan penggantian sebagian air $(1 / 4$ - 1 bagian) selama proses perendaman dapat menghasilkan lada putih yang cerah karena selama proses perendaman terjadi perombakan jaringan kulit buah sehingga senyawa penyebab pencoklatan pada kulit buah akan terbawa oleh air rendaman yang terbuang. Perendaman yang terlalu lama menyebabkan produk menjadi bau dan menyebabkan kandungan minyak atsiri pada lada putih menjadi rendah (Usmiati dan Nurdjannah 2006). Menurut Rubiyanti (2009), tinggi rendahnya kadar minyak atsiri lada sangat menentukan tinggi rendahnya aroma dalam biji 
lada. Kebersihan lada putih yang dihasilkan juga dipengaruhi oleh kualitas air yang digunakan untuk perendaman lada.

Tujuan dilakukannya penelitian ini adalah untuk memberikan penjelasan kepada masyarakat sekaligus menjawab pertanyaan masyarakat mengenai kriteria panen dan metode perendaman yang baik dan bisa dilakukan petani sehingga menghasilkan lada yang sesuai dengan Standar Nasional Indonesia.

\section{Bahan dan Metode}

Penelitian dilaksanakan di Dusun Tanah Merah Desa Baskara Bakti Kec. Namang Kabupaten Bangka Tengah kemudian dilakukan pengujian di Balai UPTD Sertifikasi dan Pengendalian Mutu Dinas Perindustrian dan Perdagangan Kepulauan Bangka Belitung dan Laboratorium Badan Lingkungan Hidup Kepulauan Bangka Belitung.

Alat - alat yang digunakan pada penelitian ini adalah karung, timbangan, kamera, selang air ukuran 5/8 in, ember plastik dengan kapasitas 18 liter, mesin pompa air, tudung saji, alat penjernih air (fertilasi), dan alat laboratorium (kaca arloji, heating mentel, alumunium foil, timbangan analitik, gelas ukur, gelas piala, pinset, kertas saring, labu destilasi, labu takar, pendingin refluk, penggiling mekanis, ayakan, spectrometer dan buku petunjuk standar Indonesia). Bahan - bahan yang digunakan pada penelitian ini adalah lada putih (Muntok White Pepper) varietas Lampung Daun Kecil (LDK), air dan bahan - bahan kimia (etanol $70 \%$ dan 65 $\%$, aquades, toluene, dan batu didih).

Penelitian ini menggunakan Rancangan Acak Kelompok Faktorial (RAKF) dengan 3 ulangan dari 2 faktor perlakuan. Faktor pertama adalah matang fisiologis (M). Matang fisiologis sebagai faktor pertama dengan simbol (M) yang terdiri dari 3 taraf perlakuan yaitu :

M1 = menjelang matang optimum (Gambar 1a),

M2 = matang optimum (Gambar 1b)

M3 = lewat matang optimum (Gambar 1c)

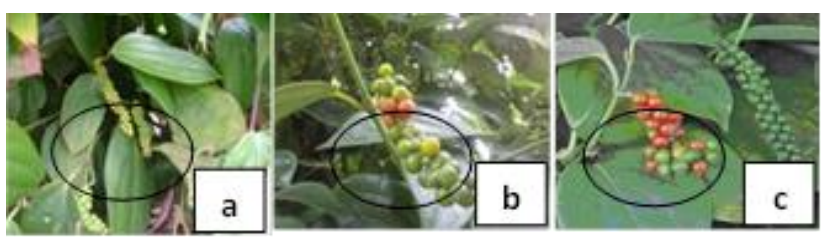

Gambar 1 Buah lada menjelang matang optimum (a), buah lada matang optimum (b), buah lada lewat matang optimum (c)

Faktor kedua adalah metode perendaman dengan simbol (P) yang terdiri dari 3 taraf perlakuan yaitu :
$\mathrm{P} 1$ = tidak mengalir (tidak ada pergantian air)

P2 = air mengalir

P3 = sirkulasi air

sehingga diperoleh 9 kombinasi perlakuan dengan 27 unit percobaan.

\section{Metode Perendaman Lada}

Metode perendaman air tidak mengalir yaitu memasukan karung yang berisi buah lada kedalam ember plastik yang telah terisi air dengan posisi tergenang air dan tidak dilakukan pergantian air selama waktu perendaman. Metode perendaman air mengalir yaitu karung yang berisi buah lada direndam didalam air sungai yang mengalir setiap waktu sampai waktu perendaman selesai. Metode perendaman sirkulasi air yaitu proses perendaman dimana terjadi suatu perputaran air yang dibantu menggunakan mesin pompa air dan selanjutnya di saring menggunakan alat filter sederhana yang dibuat sendiri. Perendaman dilakukan selama 12 hari untuk semua metode perendaman (Usmiati dan Nurdjanah 2006).

\section{Pembersihan Lada}

Pembersihan kulit dan pemisahan tangkai lada dengan cara menggosok buah lada pada permukaan tudung saji. Pembersihan dilakukan secara manual sekaligus pemisahan tangkai buah dan kotoran lainnya. Pengeringan dilakukan pengeringan dibawah sinar matahari dari pukul 08.00-17.00 (Usmiati dan Nurdjanah). Menurut Balitri (2002) pengeringan dilakukan selama 3-7 hari sampai kadar airnya rendah

\section{Analisis Uji Mutu Lada}

Analisis uji mutu lada dilakukan di laboratorium pengujian Balai Sertifikasi dan Pengendalian Mutu Dinas Perindustrian dan Perdangan Provinsi Bangka Belitung dan Badan Lingkungan Hidup Provinsi Bangka Belitung. Pengujian ini mengacu pada Badan Standarisasi Nasional yaitu SNI 0004:1995 dan SNI 0004:2013.

\section{Analisis Data}

Peubah yang diamati yaitu kadar benda asing (\%), kadar cemaran kapang (\%), kadar lada putih berwarna kehitam-hitaman (\%), kadar biji enteng (\%), kadar air (\%), kadar piperin (\%), kadar minyak atsiri (\%), dan warna. Semua pengujian mengacu kepada SNI 0004:2013 kecuali peubah warna yang mengacu kepada SNI 0004:1995. Data hasil penelitian dianalisis secara statistik diuji melalui analisis varian (uji F) dengan taraf kepercayaan 95\%. Jika diperoleh $\mathrm{F}$ hitung lebih besar dari $\mathrm{F}$ tabel, maka dilakukan uji lanjut Duncan Multiple Range Test (DMRT) dengan 
tingkat kepercayaan 95\% untuk menentukan beda nyata. Analisis data menggunakan program aplikasi Statistical Analitic System (SAS).

\section{Hasil}

Hasil uji analisis matang fisiologis dan metode perendaman terhadap aspek fisik dan kimia lada putih (Muntok White Pepper) seperti terlihat pada Tabel 1. Tabel 1 menunjukan matang fisiologis berpengaruh nyata terhadap peubah kadar lada berwarna kehitam - hitaman dan kadar biji enteng, namun matang fisiologis tidak berpengaruh nyata terhadap peubah yang lainnya yaitu kadar benda asing, kadar air, kadar piperin dan kadar minyak atsiri. Metode perendaman berpengaruh nyata terhadap peubah kadar biji enteng, akan tetapi metode perendaman tidak berpengaruh nyata terhadap peubah kadar benda asing, lada berwarna kehitam - hitaman, kadar air, kadar piperin dan kadar minyak. Peubah cemaran kapang baik pada matang fisiologis maupun metode perendaman hasilnya 0 dikeranakan tidak ditemukan satupun lada yeng terdapat cemaran kapang. Tabel 1 menunjukan intraksi matang fisiologis dengan metode perendaman tidak berpengaruh nyata terhadap semua peubah. Hal ini menunjukan bahwa tidak terjadi interaksi antara matang fisiologis dengan metode perendaman.

Tabel 1. Hasil sidik ragam uji analisis matang fisiologis dan metode perendaman terhadap aspek fisik dan kimia lada putih (Muntok White Pepper)

\begin{tabular}{|c|c|c|c|c|c|c|c|}
\hline \multirow{2}{*}{ Peubah yang diamati } & \multicolumn{2}{|c|}{$\begin{array}{l}\text { Matang } \\
\text { fisiologis }\end{array}$} & \multicolumn{2}{|c|}{$\begin{array}{c}\text { Metode } \\
\text { perendaman }\end{array}$} & \multicolumn{2}{|c|}{ Intraksi } & \multirow[t]{2}{*}{ KK (\%) } \\
\hline & F hit & Pr $>\mathbf{f}$ & F hitung & Pr $>\mathbf{f}$ & F hit & Pr $>f$ & \\
\hline Kadar benda asing & $0.48^{\text {tn }}$ & 0.6251 & $0.78^{\mathrm{tn}}$ & 0.4754 & $0.63^{\mathrm{tn}}$ & 0.6491 & 72.61 \\
\hline Kadar cemaran kapang & - & - & - & - & - & - & - \\
\hline $\begin{array}{l}\text { Kadar lada berwarna kehitam - } \\
\text { hitaman }\end{array}$ & $20.06^{*}$ & 0.0001 & $1.33^{\mathrm{tn}}$ & 0.2920 & $0.67^{\mathrm{tn}}$ & 0.6252 & 71.93 \\
\hline Kadar biji enteng & $8.64^{*}$ & 0.0029 & $9.14^{*}$ & 0.0023 & $2.24^{\mathrm{tn}}$ & 0.1104 & 41.90 \\
\hline Kadar air & $0.08^{\mathrm{tn}}$ & 0.9220 & $1.71^{\mathrm{tn}}$ & 0.2116 & $1.06^{\mathrm{tn}}$ & 0.4075 & 2.52 \\
\hline Kadar piperin & $0.35^{\mathrm{tn}}$ & 0.7082 & $0.56^{\mathrm{tn}}$ & 0.5795 & $1.74^{\mathrm{tn}}$ & 0.1896 & 10.04 \\
\hline Kadar minyak atsiri & $0.60^{\operatorname{tn}}$ & 0.5619 & $0.13^{\mathrm{tn}}$ & 0.8775 & $1.12^{\mathrm{tn}}$ & 0.3816 & 12.10 \\
\hline
\end{tabular}

Keterangan : tn : : tidak berpengaruh nyata

: berpengaruh nyata

Tabel 2 menunjukan bahwa matang fisiologis berpengaruh nyata terhadap kadar lada berwarna kehitam - hitaman. Fase lewat matang optimum menunjukan kadar lada berwarna kehitam hitaman paling tinggi yaitu $0,12 \%$ dan pada fase menjelang matang optimum menunjukan kadar lada berwarna kehitam - hitaman paling rendah yaitu $0,01 \%$. Matang fisiologis berpengaruh nyata terhadap kadar biji enteng. Fase menjelang matang optimum menunjukan kadar biji enteng paling tinggi yaitu $1,66 \%$ dan pada fase lewat matang optimum menunjukan kadar biji enteng paling kecil yaitu $0,79 \%$.

Tabel 3 menunjukan metode perendaman berpengaruh nyata terhadap kadar biji enteng. Metode perendaman dengan air mengalir menunjukan kadar biji enteng lebih tinggi yaitu $1,64 \%$ dan yang paling kecil ditunjukan pada metode perendaman air tidak mengalir yaitu $0,71 \%$.
Tabel 2. Hasil uji lanjut (DMRT) pengaruh matang fisiologis terhadap kadar lada berwarna kehitam - hitaman dan kadar biji enteng.

\begin{tabular}{lcc}
\hline \multicolumn{1}{c}{ Perlakuan } & $\begin{array}{c}\text { lada } \\
\text { berwarna } \\
\text { kehitam- } \\
\text { hitaman (\%) }\end{array}$ & $\begin{array}{c}\text { Kadar biji } \\
\text { enteng }\end{array}$ \\
\hline $\begin{array}{l}\text { Menjelang } \\
\text { matang } \\
\text { optimum }\end{array}$ & $0.01 \mathrm{~b}$ & $1.66 \mathrm{a}$ \\
$\begin{array}{l}\text { Matang } \\
\text { optimum }\end{array}$ & $0.03 \mathrm{~b}$ & $0.94 \mathrm{~b}$ \\
$\begin{array}{l}\text { Lewat matang } \\
\text { optimum }\end{array}$ & $0.12 \mathrm{a}$ & $0.79 \mathrm{~b}$ \\
\hline $\begin{array}{l}\text { keterangan : Angka yang diikuti huruf yang sama pada } \\
\text { kolom yang sama menunjukan tidak } \\
\text { berbeda nyata pada uji lanjut DMRT taraf } \\
\text { kepercayaan 95\%. }\end{array}$
\end{tabular}

Gambar 2 menunjukan bahwa kadar air lada cenderung meningkat pada perlakuan matang fisiologis fase matang optimum dan cendrung menurun pada fase menjelang matang optimum. 
Kadar air cenderung meningkat pada perlakuan metode perendaman air mengalir dan yang cenderung menurun pada metode sirkulasi air.

Tabel 3. Hasil uji lanjut Duncan Multiple Range Test (DMRT) pada pengaruh metode perendaman terhadap kadar biji enteng.

\begin{tabular}{lc}
\hline \multicolumn{1}{c}{ Perlakuan } & Kadar biji enteng \\
\hline Air tidak mengalir & $0,71 \mathrm{~b}$ \\
Air mengalir & $1,64 \mathrm{a}$ \\
Sirkulasi air & 1,03 \\
\hline
\end{tabular}

keterangan : Angka yang diikuti huruf yang sama pada kolom yang sama menunjukan tidak berbeda nyata pada uji lanjut Duncan Multiple Range Test (DMRT) pada taraf kepercayaan 95\% dengan a 5\%. (SNI kadar biji enteng mutu I maks $1,0 \%$ dan mutu II maks 2,0 \%).

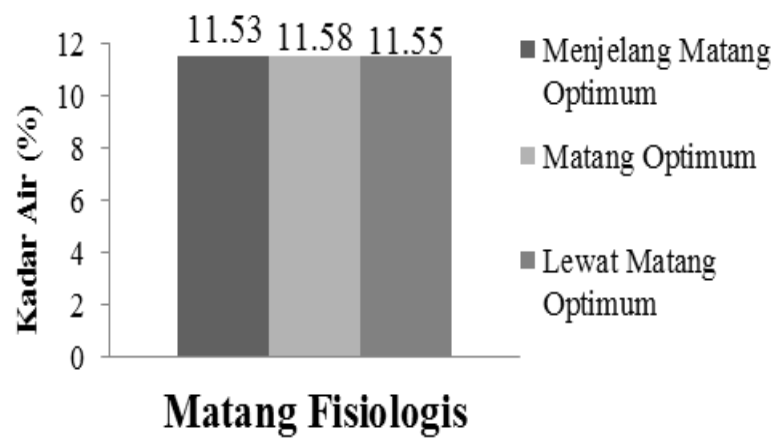

(a)
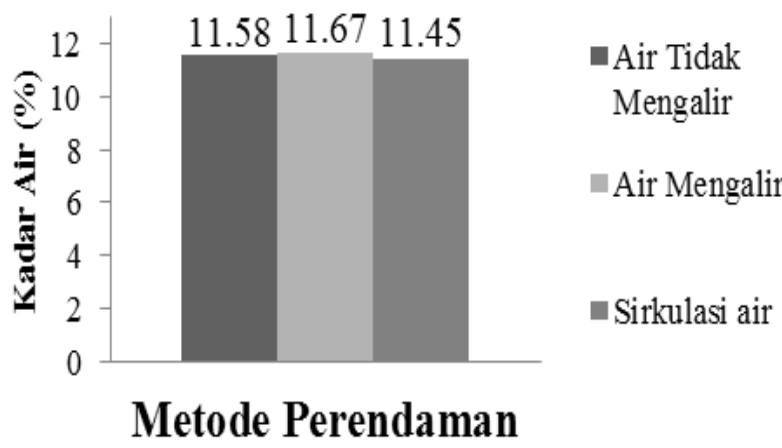

\section{(b)}

Gambar 2. Rerata persentase kadar air lada berdasarkan pengaruh matang fisiologis (a) dan metode perendaman (b) terhadap kadar air lada. (SNI kadar air mutu I maks 13,00 \% dan mutu II maks $14,00 \%)$.

Gambar 3 menunjukan bahwa kadar minyak atsiri cenderung meningkat pada perlakuan matang fisiologis fase menjelang matang optimum dan cenderung menurun pada fase matang optimum. Kadar minyak atsiri cenderung meningkat pada perlakuan metode perendaman metode air tidak mengalir dan cenderung menurun pada metode air mengalir.

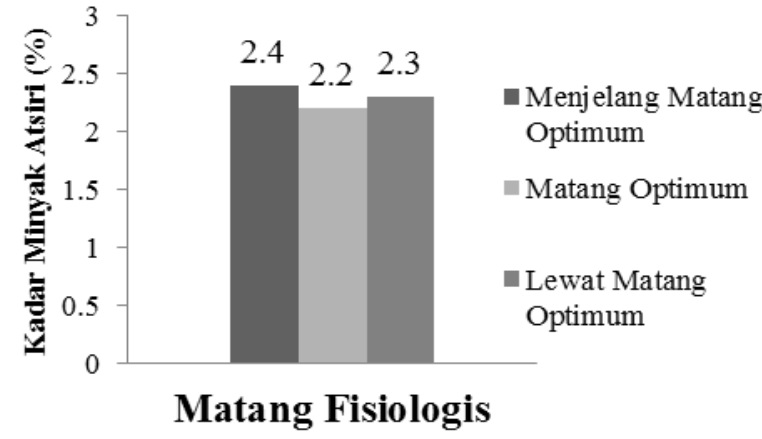

(a)

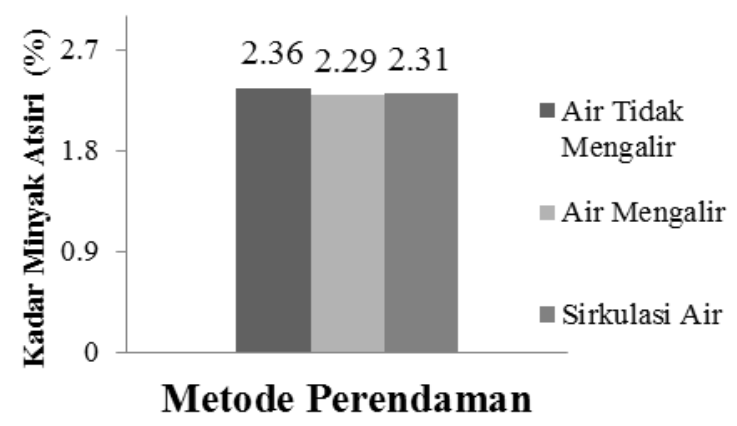

(b)

Gambar 3. Rerata persentase kadar minyak atsiri berdasarkan pengaruh matang fisiologis (a) dan metode perendaman (b). (SNI kadar minyak atsiri mutu I dan II sesuai hasil pengujian)

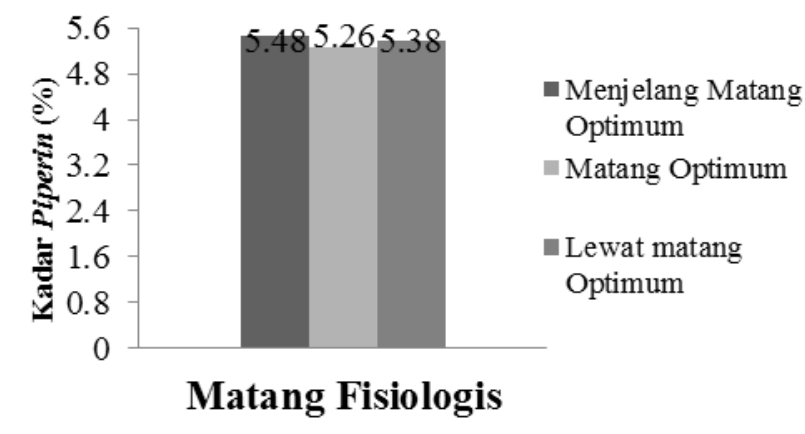

(a)

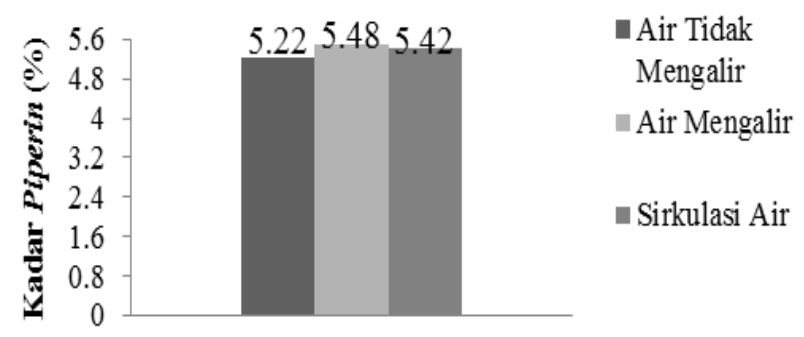

Metode Perendaman

(b)

Gambar 4. Rerata persentase kadar piperin berdasarkan pengaruh matang fisiologis (a) dan metode perendaman (b). ( SNI kadar piperin mutu I dan II sesuai hasil pengujian). 
Gambar 4 menunjukan bahwa kadar piperin cenderung meningkat pada perlakuan matang fisiologis fase menjelang matang optimum dan cenderung menurun pada fase matang optimum. Kadar piperin yang cenderung meningkat pada perlakuan metode perendaman air mengalir dan yang cenderung menurun pada metode air tidak mengalir.

Gambar 5 menunjukan bahwa kadar benda asing cenderung meningkat pada perlakuan matang fisiologis fase matang optimum dan cenderung menurun pada fase menjelang matang optimum. Kadar benda asing cenderung meningkat pada perlakuan perendaman metode sirkulasi air dan cenderung menurun terjadi pada metode air tidak mengalir.

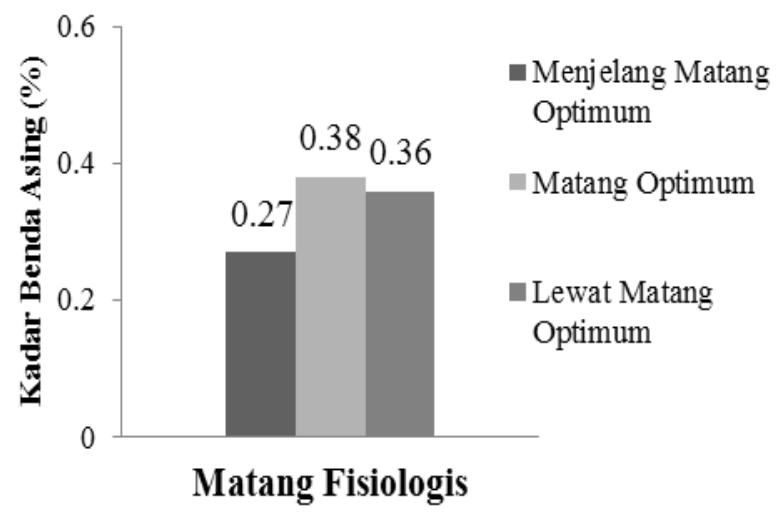

(a)

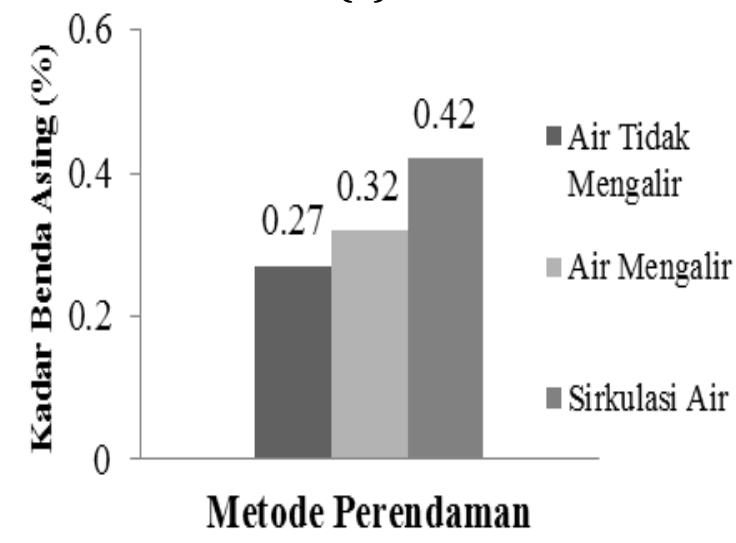

(b)

Gambar 5. Rerata persentase kadar benda asing berdasarkan pengaruh matang fisiologis (a) dan metode perendaman terhadap kadar benda asing (b). (SNI kadar benda asing mutu I maks 1,0 \% dan mutu II maks 2,0 \%)

Gambar 6 menunjukkan bahwa kadar lada berwarna kehitam - hitaman cendrung meningkat pada perlakuan metode perendaman air mengalir dan cendrung menurun pada metode perendaman air tidak mengalir.

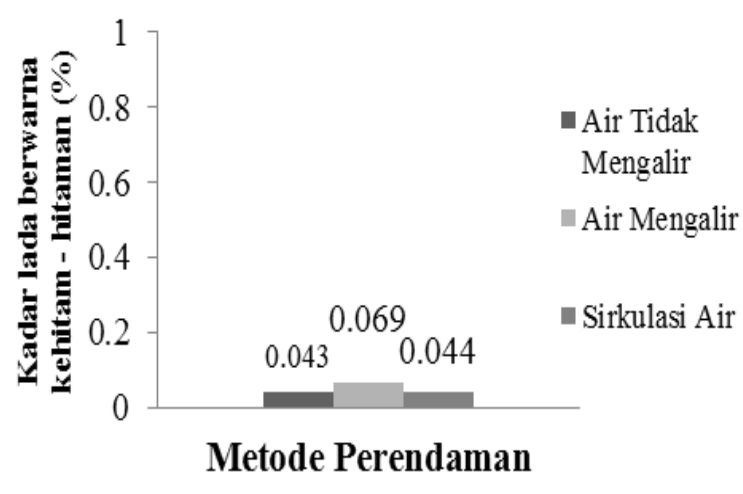

Gambar 6. Rerata persentase pengaruh metode perendaman terhadap kadar lada berwarna kehitam - hitaman. ( SNI kadar lada berwarna kehitam - hitaman mutu I maks 1,0 \% dan mutu II maks 2,0 $\%)$

Berdasarkan hasil penelitian yang diperoleh menunjukan bahwa warna lada hasil penelitian baik pada perlakuan matang fisiologis maupun metode perendaman memiliki perbedaan yang tidak begitu signifikan. Pada dasarnya peubah warna tidak lagi masuk kedalam Standar Nasional Nasional (2013) sehingga untuk peubah ini tidak lagi menjadi acuan. Menurut Standar Nasional Indonesia (1995) warna lada putih terdiri dari mutu I (putih kekuning - kuningan) dan mutu II (putih kecoklatan dan putih keabu - abuan). Hasil penilitian menunjukan warna lada yang diperoleh masuk kedalam mutu II yaitu berwarna putih keabu - abuan dan putih kecoklat - coklatan.

\section{Pembahasan}

\section{Kadar Air}

Tabel 1 menunjukan bahwa perlakuan matang fisiologis dan metode perendaman tidak berpengaruh nyata terhadap kadar air biji lada. Berdasarkan persentase kadar air (Gambar 2), kadar air lada hasil penelitian dapat memenuhi Standar Nasional Indonesia (SNI) baik untuk kelas mutu I maupun mutu II. Tinggi rendahnya kadar air biji lada dipengaruhi pada saat proses pengeringan. Pengeringan dapat dilakukan dengan melakukan penjemuran di bawah sinar matahari langsung atau di dalam alat pengeringan. Tinggi rendahnya kadar air biji lada akan berpengaruh terhadap daya simpan lada. Semakin rendah kadar air biji lada maka akan semakin lama waktu penyimpanan dan sebaliknya jika kadar air tinggi waktu penyimpanan akan semakin pendek. Menurut Hidayat et al. (2009) kadar air berhubungan dengan daya awet produk, semakin tinggi kadar air suatu produk maka mikroba akan 
lebih mudah tumbuh. Menurut Direktorat Pascapanen dan Pembinaan Usaha (2012) Proses pengeringan di tingkat petani dilakukan dengan dijemur, dimana hal tersebut sangat tergantung dari keadaan cuaca. Cuaca yang kurang baik mengakibatkan proses pengeringan menjadi lambat dan lada menjadi berjamur. Menurut Balitri (2002) pengeringan dilakukan selama 3-7 hari sampai kadar airnya rendah.

\section{Kadar Lada Berwarna Kehitam - hitaman}

Tabel 1 menunjukan bahwa perlakuan matang fisiologis berpengaruh nyata terhadap peubah kadar lada berwarna kehitam - hitaman. Perlakuan metode perendaman tidak berpengaruh nyata terhadap kadar lada berwarna kehitam-hitaman. Berdasarkan persentase kadar lada berwarna kehitam - hitaman pada Tabel 2 dan Gambar 6, kadar lada berwarna kehitam - hitaman hasil penelitian dapat memenuhi Standar Nasional Indonesia (SNI) baik mutu I maupun Mutu II. Persentase kadar lada berwarna kehitam hitaman menunjukan bahwa kadar lada berwarna kehitam - hitaman tertinggi ditunjukan pada fase lewat matang optimum (Tabel 2). Tingginya kadar lada berwarna kehitam - hitaman pada lada fase lewat matang optimum di duga disebabkan oleh meningkatnya aktivitas reaksi pencoklatan enzimatis yang dikatalisasi oleh enzim odifenol oksidase. Menurut Pongsakul et al. dalam Hidayat et al. (2012), dengan adanya oksigen enzim akan mengkatalisis senyawa fenol melalui dua reaksi yaitu hidroksilasi monofenol menjadi odifenol dan oksidasi odifenol menjadi kuinon, elanjutnya kuinon mengalami polimerisasi membentuk senyawa polimer (melanin) yang berwarna kecoklatan/kehitaman.

Tren meningkatnya kadar lada berwarna kehitam - hitaman pada perlakuan metode air mengalir (Gambar 6) diduga kandungan oksigen terlarut dalam air mengalir lebih tinggi dibandingkan dengan kandungan oksigen terlarut pada metode air tidak mengalir dan sirkulasi air. Penyebab tingginya kandungan oksigen terlarut pada metode air mengalir salah satunya adalah di karenakan limbah yang di hasilkan pada proses perendaman lada terus terbawa oleh aliran air sehingga limbah pada metode perndaman air mengalir lebih sedikit dibandingkan pada metode air tidak mengalir dan sirkulasi air. Menurut Alamanda et al. (2012) penurunan oksigen terlarut pada setiap lokasi diduga disebabkan tingginya aktivitas dekomposisi bahan organik yang berasal dari kegiatan pada daerah aliran sungai, seperti limbah pasar dan limbah rumah tangga. Menurut sutikno (2008) pada umumnya umbi-umbian dan buah-buahan mengalami pencoklatan setelah dikupas. Hal ini disebabkan oksidasi dengan udara bebas sehingga terbentuk reaksi pencoklatan oleh pengaruh enzim yang terdapat dalam bahan pangan tersebut (browning enzymatic). Pencoklatan karena enzim merupakan reaksi antara oksigen dan suatu senyawa fenol yang dikatalisis oleh Polyphenol oksidase. Proses pencoklatan enzimatik memerlukan adanya enzim fenol dan oksigen yang harus berhubungan dengan substrat tersebut.

\section{Kadar Biji Enteng}

Tabel 1 menunjukan perlakuan matang fisiologis dan metode perendaman berpengaruh nyata terhadap peubah kadar biji enteng. Berdasarkan persentase kadar biji enteng (Tabel 2 dan 3), kadar biji enteng lada hasil penelitian dapat memenuhi standar SNI mutu II. Persentase kadar biji enteng (Tabel 2), menunjukan bahwa kadar biji enteng tertinggi pada perlakuan matang fisiologis ditunjukan pada fase menjelang matang optimum dan kadar biji enteng tertinggi pada perlakuan metode perendaman ditunjukan pada metode air mengalir (Tabel 3). Faktor yang menyebabkan tingginya kadar biji enteng pada fase menjelang matang optimum adalah waktu pemanenan dan kondisi kenormalan buah. Buah lada yang di petik terlalu muda dapat meningkatkan kadar biji enteng dan sebaliknya jika buah lada yang dipetik sudah matang optimum maka kadar biji enteng semakin menurun. Meningkatnya ketidaknormalan pada buah lada akan meningkatkan kadar biji enteng pada buah lada. Menurut Hidayat et al. (2009) lada enteng merupakan lada putih yang memiliki bobot lebih ringan dari bobot normal lada putih, yang umumnya disebabkan oleh pemetikan (panen) muda atau buah tidak normal tumbuhnya.

Tingginya kadar biji enteng pada perlakuan metode perendaman dengan air mengalir disebabkan oleh tingginya kandungan oksigen terlarut dalam air mengalir yang mempu mempercepat terjadinya respirasi sehingga biji lada semakin cepat rusak. Menurut Nurjanah (2002) respirasi adalah suatu proses yang melibatkan terjadinya penyerapan oksigen $\left(\mathrm{O}_{2}\right)$ dan pengeluaran karbondioksida $\left(\mathrm{CO}_{2}\right)$ serta energi yang digunakan untuk mempertahankan reaksi metabolisme dan reaksi lainnya yang terjadi di dalam jaringan. Hasil penelitian Paramita (2010) menunjukan dengan menurunkan konsentrasi $\mathrm{O}_{2}$ atau meningkatkan konsentrasi $\mathrm{CO}_{2}$, maka laju respirasi dapat diperlambat sehingga umur simpan dapat diperpanjang. 


\section{Kadar Minyak Atsiri}

Tabel 1 menunjukan bahwa perlakuan matang fisiologis dan metode perendaman tidak berpengaruh nyata terhadap kadar minyak atsiri biji lada putih. Berdasarkan persentase kadar minyak (Gambar 3), minyak atsiri lada hasil penelitian dapat memenuhi standar ASTA,ESA dan ISO yang mana kadar minyak atsiri minimal standar ASTA dan ESA 1,5 \%, ISO $2 \%$. Purwanto (2011) menyebutkan bahwa kadar minimal minyak atsiri untuk standar ASTA dan ESA sebesar 1,5\%. Risfaheri (1996) menambahkan Standar ISO untuk kadar minyak atsiri minimal $2 \%$.

Tinggi rendahnya kadar minyak atsiri biji lada dipengaruhi oleh faktor varietas, umur dan cara penyulingan. Guenther (1972) dalam Nurdjanah dan Hoerudin (2007), menyatakan kadar minyak atsiri suatu bahan dipengaruhi oleh varietas, lingkungan geografis pertumbuhan, umur dan kualitas bahan baku yang digunakan serta cara penyulingan. Penelitian yang dilakukan menggunakan bahan baku dengan varietas, lingkungan pertumbuhan, umur dan mutu bahan yang sama demikian juga dengan cara penyulingannya sehingga tidak ditemukan perbedaan yang signifikan pada kadar minyak atsiri. Menurut Rismunandar (2003) Kadar minyak atsiri dan kadar bahan yang tidak menguap (nonvolatile extract) sangat tergantung dari jenis lada. Tinggi rendah kadar minyak lada menentukan tinggi rendah nilai aroma jenis biji lada. Minyak lada yang baik dapat diperoleh melalui destilasi uap air. Risfaheri (2012) menambahkan bahwa komposisi kadar minyak atsiri dan piperin menunjukkan peningkatan sampai menjelang matang penuh dan setelah itu menurun selama periode pemasakan buah.

\section{Kadar Piperin}

Tabel 1 menunjukan bahwa perlakuan matang fisiologis dan metode perendaman tidak berpengaruh nyata terhadap kadar piperin lada putih. Berdasarkan persentase kadar piperin (Gambar 4), kadar piperin lada hasil penelitian dapat memenuhi Standar ASTA dan ISO yang mana kadar piperin minimal standar ASTA dan ISO yaitu 4\%. Menurut Purwanto (2011) mengatakan bahwa pada standar ASTA dan ISO persyaratan kadar minimal piperin adalah 4\%. Berdasarkan rata rata persentase kadar piperin menunjukan bahwa kadar piperin cendrung meningkat pada fase menjelang matang optimum. Hal ini sesuai dengan yang ditemukan Risfaheri (2012) yang menyatakan bahwa komposisi kadar minyak atsiri dan piperin menunjukkan peningkatan sampai menjelang matang penuh dan setelah itu menurun selama periode pemasakan buah. Tinggi rendahnya kadar piperin selain dipengaruhi oleh faktor umur buah juga diduga karena terjadinya penguraian kandungan piperin menjadi senyawa sederhana.

Menurut Guenther (1952) dalam Djubaedah et al. (2004) penurunan piperin dapat terjadi karena terurainya piperin menjadi asam piperat piperidin dalam suasana asam. Bruneton (1999) dalam Djubaedah et al. (2004) menambahkan bahwa piperin berbentuk kristal jarum berwarna kuning, tidak berbau, tidak berasa lama-lama pedas. Piperin bila dihidrolisis dengan $\mathrm{KOH}$ akan menghasilkan kalium piperinat dan piperidin

\section{Kadar Benda Asing}

Tabel 1 menunjukan bahwa perlakuan matang fisiologis dan metode perendaman tidak berpengaruh nyata terhadap kadar benda asing. Berdasarkan persentase kadar benda asing (Gambar 5), kadar benda asing lada hasil penelitian dapat memenuhi Standar Nasional Indonesia (SNI) baik untuk kelas mutu I maupun mutu II. Kadar benda asing merupakan benda lain yang terdapat di dalam hasil panen lada selain biji dari lada putih tersebut seperti tangkai, kulit, daun, pasir, tanah dan batu - batuan. Faktor yang menyebabkan tingginya kadar benda asing diduga bukan disebabkan oleh tingkat kematangan buah ataupun metode perendaman, tetapi karena disebabkan oleh faktor disaat pencucian dan lingkungan.

Pencucian merupakan salah satu kegiatan yang perlu di perhatikan untuk mengurangi tingginya kadar benda asing. Ketelitian dalam melakukan pencucian akan berpengaruh terhadap tinggi rendahnya kadar benda asing misalnya pada proses pemisahan kulit dari biji, pemisahan tangkai dari biji dan lain sebagainya. Faktor lingkungan yang perlu diperhatikan pada penanganan pasca panen lada adalah disaat dilakukannya penjemuran. Lada yang di jemur di hamparan tanah akan menyebabkan banyaknya benda - benda asing yang masuk kedalam wadah penjemuran sehingga semakin tinggi kadar benda asingnya. Menurut Purwanto (2011) untuk memperoleh lada dengan kadar benda asing rendah maka proses penanganan pasca panen lada harus dilakukan dengan higienis, menghindarkan penghamparan lada di tanah tanpa alas atau penjemuran di pinggir jalan.

\section{Kadar Cemaran Kapang}

Berdasarkan hasil sidik ragam (Tabel 1) lada hasil penelitian tidak ditemui cemaran kapang. Hal ini menunjukan bahwa kadar air lada hasil 
penelitian terbilang rendah sehingga tidak ada cemaran kapang pada lada hasil penelitian. Ciri-ciri lada yang terkena kapang adalah adanya bercakbercak coklatan, kehitaman dan bulukan pada biji lada yang bisa terlihat secara visual. Cemaran kapang yang biasa terdapat pada lada putih adalah Aspergillus spp. Ahmad (2009) menyebutkan, di Indonesia jenis kapang Aspergillus spp merupakan jenis kapang yang dominan mencemari pakan (biji - bijian), sehingga untuk mengurangi terjadinya kontaminasi dan toksin pada pakan (biji - bijian) perlu dilakukan beberapa faktor pendukung seperti suhu dan kelembaban agar penyebarannya tidak meningkat. Usmiati dan Nurdjannah (2006) menambahakan bahwa jenis kapang Aspergillus fumigatus, Aspergillus flavus dan Saccharomyces sp merupakan jenis kapang atau jamur yang sering dijumpai pada lada petani.

\section{Warna}

warna merupakan salah satu peubah yang kerap sekali diperbincangkan dikalangan masyarakat petani lada di Provinsi Kepulauan Bangka Belitung dalam menentukan mutu lada putih (Muntok white pepper). Berdasarkan Standar Nasional Indonesia tahun 2013 peubah warna tidak dimasukan lagi, namun untuk menambah informasi bahwasanya warna lada hasil penelitian ini baik pada perlakuan matang fisiologis maupun metode perendaman memberikan hasil berwarna putih keabu - abuan atau putih kecoklat - coklatan (mutu II). Menurut Vargas et al (2001) dalam Mawarti dan Widaningrum (2007) melaporkan bahwa perubahan warna dapat dipengaruhi oleh banyak faktor, tidak hanya karakteristik dari zat warna yang bersangkutan tetapi juga proses antara lain lama dan suhu pemanasan, tekanan selama pengolahan dan pemakaian tutup pada alat pengolah. Lada putih memiliki kandungan tannin yang mudah larut dalam air dan menyebabkan biji lada berwarna kecoklatan hingga kehitaman (Muchtadi 1989).

\section{Kesimpulan}

1. Perlakuan matang fisiologis dan metode perendaman mempengaruhi kadar lada berwarna kehitam - hitaman dan kadar biji enteng.

2. Buah lada pada kondisi menjelang matang optimum cenderung memberikan hasil lada putih (Muntok White Pepper) yang lebih baik serta memenuhi standar SNI yang dilihat dari aspek visual dan fisiko kimianya.

3. Metode perendaman air tidak mengalir cenderung memberikan hasil lada putih
(Muntok White Pepper) yang lebih baik serta memenuhi standar SNI yang dilihat dari aspek visual dan fisiko kimianya.

\section{Daftar Pustaka}

Ahmad ZR. 2009. Cemaran Kapang Pada Pakan dan Pengendaliannya. [Jurnal]. Balai Besar Penelitian Veteriner Departemen Pertanian. Jurnal Litbang Pertanian. Vol 28 (1): 15 - 22.

Alamanda S, Wiedarti S, Triastinurmiatiningsih. 2012. Kualitas Air dan Keanekaragaman Jenis Plankton Di Sungai Cisadane, Jawa Barat. Bogor: FMIPA Universitas Pakuan

[BPS] Badan Pusat Statistik Kepulauan Bangka Belitung. 2015. Kepulauan Bangka Belitung Dalam Angka 2015. Pangkalpinang: BPS Provinsi Kepulauan Bangka Belitung

Direktorat Pascapanen dan Pembinaan Usaha. 2012. Pedoman Teknis Penanganan Pascapanen Lada. Jakarta: Direktorat Pascapanen dan Pembinaan Usaha

Hidayat T, Nurdjannah N, dan Usmiati S.2009. Analisis Teknis dan Finansial Paket Teknologi Pengolahan Lada Putih (White Pepper) Semi Mekanis Bul. Littro. Vol. 20 (1): 77 - 91

Jumiaty T dan Ferry Y. 2011. Prospek Pengembangan Teknologi Pengolahan Lada Hijau Di Petani. Perspektif Balai Penelitian Tanaman Rempah dan Aneka Tanaman Industri. Vol 10 (1): 22 - 23

Mawarti, Widaningrum. 2007. Pengaruh Larutan Pengawet dan Cara Sterilisasi Terhadap Sifat Fisik, Kimia, Mikrobiologi Serta Sifat Organoleptik Produk Lada Hijau dalam Larutan Garam. Balai Besar Penelitian dan Pengembangan Pascapanen Pertanian.Vol 4 (1) 2007. Hal 44 - 56

Muchtadi D. 1989.Aspek Biokimia dan Gizi Dalam Keamanan Pangan. Bogor: IPB Press

Nurdjannah N, Hoerudin. 2007. Pengaruh Perbandingan Berat Buah Lada dengan Air dan Waktu Pemblansiran terhadap Mutu Lada Hitam yang Dihasilkan. Buletin Teknologi Pascapanen Pertanian Vol. 3

Nurjanah S. 2002. Kajian Laju Respirasi dan Produksi Etilen Sebagai Dasar Penentuan Waktu Simpan Sayuran dan Buah-Buahan. Jurnal Bionatura. Vol. 4 (3) : 148 - 156

Paramita 0. 2010. Pengaruh Memar terhadap Perubahan Pola Respirasi, Produksi Etilen dan Jaringan Buah Mangga (Mangifera Indica L) Var Gendong Gincu pada Berbagai Suhu Penyimpanan. Jurnal Kompetensi Teknik. Vol 2 (1). 
Purwanto E. 2011. Harmonisasi Standar Mutu Lada Indonesia.Warta Penelitian dan Pengembangan Tanaman Industri.Vol 17 (3): 27 - 31

Risfaheri. 1996. Masalah dan Standar Mutu Lada Monograf Tanaman Lada No.1. Bogor: Balai Penelitian Tnaman Rempah dan Obat.

Risfaheri. 2012. Diversifikasi Produk Lada (piper nigrum) untuk Peningkatan Nilai Tambah. Buletin Teknologi Pascapanen Pertanian. Vol. 8 (1): $16-26$

Rismunandar, Riski MH.2003. Budi daya dan tata niaga lada. Jakarta : Penebar Swadaya

Rubiyanti. 2009. Fermentasi Lada (piper nigrum L.) Pengaruhnya terhadap Kemudahan Pengupasan dan Kualitas Lada yang dihasilkan. [tesis]. Yogyakarta: Fakultas Teknologi Pertanian Universitas Gajah Mada
[SNI] Standar Nasional Indonesia. 2013. SNI 0004:1995. Jakarta: Badan Standardisasi Nasional Lada Putih

[SNI] Standar Nasional Indonesia. 2013. SNI 0004:2013. Jakarta: Badan Standardisasi Nasional Lada Putih

Sutikno. 2008. Pengaruh Pemblansiran Irisan Buah Sukun (Artocarpus communia) terhadap Pencoklatan dan Kadar Pati. [skripsi]. Yogyakarta: Fakultas Sains dan Teknologi Universitas Islam Negeri Sunan Kalijaga

Usmiati S dan Nurjanah N. 2006. Pengaruh Lama Perendaman dan Cara Pengeringan Terhadap Mutu Lada Putih. J. Teknologi Industri Pertanian. Vol. 16 (3): 91 - 98 